\title{
SOCIAL AND CULTURAL RELATIONS BETWEEN CHINA AND PAKISTAN IN THE CONTEXT OF OBOR
}

\author{
Azra Firdous \\ Department of Humanities \\ Greenwich University, Karachi \\ \& \\ Prof. Dr. Syed Salahuddin Ahmed \\ Canada
}

\begin{abstract}
This article relates to the Chinese multidimensional One Belt One Road Initiative (OBOR). One of the aspects of our research is the manifestation of cultural social relations between China and Pakistan. We have tried to prove that there is every likelihood that cultural onslaught of Chinese society will clash in the long run with the traditional Islamic society of Pakistan. CPEC has an economic potential. China's intention is to expand its dominance in the region, where as Pakistan will be in a position to move forward from its stagnant economy. We cannot forget the results of intermingling of socio-cultural norms, values and traditions. It may change the rules of the game. Under the canopy of euphoria, identity must not be forgotten. There is no doubt that regional connectivity would ultimately bring regional prosperity but there are serious socio culture impediments
\end{abstract}

Key Words: OBOR, Silk Road, Cultural Exchanges, CPEC, Connectivity, Stagnant economy.

\section{INTRODUCTION}

One Belt One Road (OBOR) is a multidimensional Chinese initiative. It is the combination of a land-based Silk Road and $21^{\text {st }}$ century Maritime Silk Road. OBOR is an initiative to create a shared future for mankind that would link China to the rest of the world. It was proposed in 
2013 by Chinese president Xi Jinping. It was proposed that the project will be connected with the world. It will be materialized through the network of roads, ports, infrastructure, development of railways, gas pipelines and social and cultural activities. Chinese main aim is to build OBOR. It is the revival of previous historical Silk Road. OBOR is the combination of six trade corridors that mainly cover Eurasia and periphery of Pacific, North and East Africa.

Tufail, (2017) explains The Belt and Road Initiative's main corridors as under:

1. China Mongolia-Russia Corridor.

2. New Eurasian Land Bridge.

3. China Central Asia West Asia Corridor.

4. China Indo China Peninsula Corridor.

5. China Myanmar Bangladesh India Corridor.

6. China Pakistan Economic Corridor (CPEC)

7. Last is the Maritime Silk Road which will pass through Singapore to the Mediterranean.

Chinese culture is based on the philosophies of Confucianism, Taoism and Buddhism. They totally differ and oppose the values of monotheism. For the revival of community of common values along Silk Road, a new civilization will be created on Chinese philosophy of having strong humanitarian grounds. It will bring connectivity among the population and countries of different ideologies.

World leaders gathered in Beijing to hear China's plan for global trade: the One Belt One Road Initiative. Chinese President XI Jinping said at the close of summit, "Nearly 70 countries and international organizations have signed for the mega infrastructure project" (Xiguang, 2016). "OBOR will connect more than 65 countries. That will be $62 \%$ of the world's population, around $35 \%$ of the world's trade and over $31 \%$ of the world's GDP. It will take the form of a series of highways, railways, ports, facilities for energy, telecommunications, healthcare and education" (Brown, 2018). 


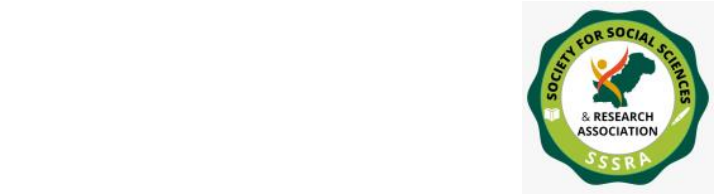

China's objective about OBOR not only focuses on its economic power but at the same time on the cultural power. In the historical context the "Silk Road empire had its own cultural sphere of governance and transportation to the farthest frontier areas to achieve trade benefits. Alexander the Great ruled the Silk Road from Greece, Persia all the way to today's Afghanistan and Pakistan" (Xiguang, 2016, pp.6-7). History witnesses the great presence of Hellenistic Kushan Empire in the western region of China through Gandharan art and Buddhism. The prosperous history of Silk Road began with the era of Great Tang Dynasty, which had military power in Central Asia and had established religious exchanges, education and cultural networks with neighboring countries. The Chinese Buddhist students got the great opportunity of travelling "through the Wakhan Corridor, the Karakorum Mountains and along the Indus River to their important religious places Swat, Peshawar and Taxila" (Xiguang, 2016).

CPEC is the hub of OBOR, a region of ancient Silk Road trading routes that have witnessed its rise and fall. The region where CPEC runs has five world's tallest mountain ranges, where the Amu and Indus Rivers sources exist. The western part of China is linked through trade routes with South Asia and Central Asia. That is the great connectivity of social and cultural exchange in the region. In this circle, many countries would have developed social and trade relations with China through tributaries. $\mathrm{Yu}$ Gong has portrayed that the ancient Silk Road civilization encircles countries that include Tajikistan, Kazakhstan, Kyrgyzstan, Afghanistan, Pakistan and Iran. The Silk Road culture and nationalities have maintained their identity since ancient times. Initiative to establish Maritime Silk Road was not the reason behind the decline of Silk Road overland routes. Actually, in mid nineteen centaury, Russia and England started expansion, concentrating on Western Asia, Central Asia and South Asia. Both countries started getting their influence in the Silk Road areas. This resulted in the blockage of the Wakhan Corridor which was the busiest route of the Silk Road, linking China, British India, Afghanistan, Central Asia and West Asia. 
Now with the OBOR initiative, China foresees re-establishing regional cultural relationship and political alliances. It is a commercial economic channel that will accelerate the human social interaction and would encircle the multi ethnic, religious, racial and cultural fusion, it has more of cultural zone platform than an economic zone.

All countries along OBOR are honoring their own social traditions, culture, history, art and architecture under their own social value setup and China has its own core values. The only thing that China needs is to design goals that suit everyone's interests and to frame a vivid slogan, adequate to accomplish a purpose of new Silk Road which can be acknowledged.

Win-win cooperation along OBOR nations is must as it would bring mutual caring, development and coexistence. These principles are entangled in the One Belt One Road that would guarantee common prosperity, development and respect for social system of OBOR nations. Every country along New Silk Road follows its culture and traditions. Civilizations along OBOR are widely dissimilar in nature but have affinities on the ground of history and culture because western powers had ruled these countries for a long period in the past.

The five major goals have been set under Chinese OBOR initiative, the fifth one is people to people bond. A successful geo-economic initiative deeply relies on this very important mechanism of people to people bond. It will achieve multilateral cooperation and connectivity along OBOR routes and infrastructure development. It is widely acknowledged but hardly discussed by experts, scholars, and media. Many countries having a stake, including China in OBOR initiative, miss the complex role of history and culture in this initiative. "At Boa Forum for Asia Annual Conference in 2015 President Xi Jinping, in his speech indicated, the Belt and Road will promote inter-civilization exchanges to build bridges of friendship for our people, drive human development and safe guard peace of the world" (Winter, 2016).

\section{RESEARCH METHODOLOGY}


Social and Cultural Relations between ..

The qualitative research method is adopted to conduct this study. Content analysis has been given prime importance because a significant theoretical portion of this research has been taken from books, online and

printed journals, web resources and news papers. For achieving integrity and authenticity, the picture of cultural norms have been evaluated and cited. This qualitative research on the topic was conducted by reviewing secondary literature available online, books, journals, articles, newspaper clipping and through media channels and seminars. Speeches and articles have been analyzed I terms of the objectives of OBOR.

\section{OBJECTIVES}

1) To analyze socio-economic scenario of OBOR in Pakistan.

2) To analyze the cultural diversities in the two countries.

3) To study in depth the nature, formation and impact of diverse Chinese culture in Pakistan.

\section{LITRATURE REVIEW}

OBOR Initiative was proposed by Chinese President Xi Jinping in 2013 therefore sufficient literature on this specific topic is not available as yet. But it would be worth mentioning that important data for the current study has been collected from the books, journals, articles, and newspapers.

Tufail(2017), has contributed valuable insight of Chinese initiative on the One Belt One Road(OBOR) with brief introduction of China's annual trade scope and regional connectivity. He has highlighted OBOR's six corridors.

Xiguang (2016) has dissipated the information about China's OBOR implementation phases and major goals. China wants the participation of other countries in this project through a dynamic civilization approach. 
Brown (2018) clearly identified the general information about Chinese Belt and Road Initiative. He has highlighted the goals that China wants to achieve through OBOR initiative. He has outlined about OBOR Corridors, key port cities, countries involved in the initiative and financial support from world institutions.

Cai (2017) has mentioned that OBOR initiative ambitious and economic policies would strengthen Beijing's economic leadership. It will be done through the means of infrastructure in the regions. One of the objectives is to upgrade, and cater China's underdeveloped areas. She has to utilize her excess production for the development of under developed areas.

Childe, \& Warner, (2003). explained the Chinese cultural life norms, values and religion. He showed concerns about cultural implications of CPEC project along the corridor routes. This article has highlighted China's Philosophy and strategy. People to people contact will bring cultural changes in Pakistani society.

\section{DATA ANALYSIS}

\section{Culture:}

Culture is a heritage of society and transfers from generation to generation. Some renowned sociologists defined culture as, "culture is everything which is socially shared and learned by the members of a society" (Horton \& Hunt, 1984, p.52).

"It is that complex whole including beliefs, art region, values, norms, ideas, law, taught, knowledge, custom and other capabilities acquired by a man as a member of a society"(Taylor, 1871, p.1).

Culture is not in born tendency, it is learned by man to man associated in the society. Culture is the outcome of social interaction. There is no concept of culture without society. It is not an individual phenomenon. Culture is adopted, shared and not transmitted through genes e.g. language, belief, customs, traditions and values, in a particular region and territory. 
"Culture is continuous, accumulative, absorbs and adopts and borrows new cultural traits. Human demands, needs, wants, desires and satisfaction are fulfilled through gratifying feature of culture. Culture and society are like twin sisters, if any change or external intervention at the level of economic, political and social norms occurs, cultural setup of the region would be challenged. In this case, the basic role of social institutions will be very important to counter such elements. It is feared that in the long run the culture and sovereignty of Pakistan will be compromised through CPEC.

\section{Pakistani Culture:}

Pakistani national culture is based on four provincial multilingual and multicultural societies. Our culture is infected by other national cultures and it is feared that it will be tempered with the influx of Chinese in Pakistan. Pakistani society has very strong religious and cultural values. There will be greater level of adaptation through interaction with Chinese alien culture. The foreign media has its own imperialist agendas. It influences the Pakistan society through its unethical cultural values.

Our culture is already being threatened by Americans, Europeans and Indians. By 2030, influx of Chinese culture would have much signs of changing cultural pattern and way of life in Pakistan. In the context of socio-cultural background, Pakistan has not been on any weak ground. It has unique ethics, values traditions, norms and beliefs. Altogether they form the national culture. Mostly we have seen that strong cultural imperialism, over shadows the weaker one, therefore the economically backward cultures adopts language, a new way of life and values of other culture (Hussain, 2017).

Backward Tribal system in Balochistan and feudal system are very rigid systems. They keep intact their cultural and traditional norms and values. They don't allow any cultural and modernist changes within their domain. This can't remain permanent. Benefits of advancement, ideas, knowledge, skills, technology and economic development are bound to bring positive attitudinal changes. Besides, China would expand the spectrum of educational opportunities for Pakistani students. This stimulus will be very attractive for the young generation but this will infuse their mind with Chinese value and highly prodigious progress. Pakistan China 
friendship is universally acknowledged and passed through many unpredictable occurrences of national and global politics. Karakoram highway development was started in 1959 and was completed in 1978; many Chinese workers have sacrificed their lives during construction.

By 2025 to 2030 CPEC will be completed, through major economic development. People to people connection for such a long period of time, would bring significant socio cultural spillover, change the thinking approach of Pakistani society after observing the benefits from Chinese work culture of Chinese and Confucius ethics. People would like to follow work culture of Chinese and Confucius ethics.

\section{Socio - Cultural Directions of China:}

CPEC has many pros and cons. It needs suitable performance in the interest of nations. The CPEC is hardly being discussed in socio culture implications. Both China and Pakistan have totally different religion, norms and practices. Not a single aspect of religion is common, except humanity. The regions through which CPEC project passes, whether North, East, West and South would have socio-cultural implications. On paper China is still a Socialist Country. With its characteristics China's cultural life is dominated by Confucian norms and roots and based on Buddhism and Atheism. Socialist country government system supports, the political philosophy of socialism that advocates community ownership and control of all lands and business rather than individual ownership.

Chinese population religiously follows Confucian teachings, epitomize consistency, discipline and result oriented approach. Family values, harmony, work ethics, respect for authority, hierarchy, are considered as tools for efficient management. On these virtues Chinese people have earned, peace full development in their country. Chinese workers have been working on development projects in Pakistan and other third world countries for decades. We have not seen any negative behavioral alarming situation from their side. They follow Confucian norms and values and earn gratitude and respect from local people.

China has noninterventionist aid philosophy and strategy. She only focuses on completing projects in time. Western aid philosophy is quite 
different. They attach themselves with the domestic politics of their host countries and favors Partisan. Mutual trust between south Asian countries particularly neighboring countries such as Afghanistan, Iran, and India would develop and facilitate the entrance to regional connectivity. Still we cannot ignore the differences of religion and cultural, between two countries Pakistan and China (Childe \& Warner, 2003).

\section{Cultural Historical Background of China}

\section{Ethnicity}

The People's Republic of China (PRC) is one of the oldest complex and most continuous culture in the world. Since 1949, the Communist regime has enforced massive institutional changes in every field of life. China's long complex history has deeply influenced Chinese culture, and deeply engraved ethnic diversity from provinces to towns with different customs and traditions. China is one of the four ancient civilizations (alongside Babylon, India and Egypt). Chinese scholar Liang Qichao (1900) traced Shang Dynasty back to around 1766 BCE. The Shang was defeated by Zhou in $1059 \mathrm{BCE}$ and ruled nearly one thousand years. Chinese first emperor Qin in $221 \mathrm{BCE}$ united various war lords. He was deadly against Confucius teaching, ruled his dynasty with an iron fist. People were forced to construct canals roads and defensive walls and construction of the "Great Wall" are the signs of that era. Qin ruled only three years. The Han Dynasty ruled from 206 BCE until 220 A.D framed characteristic of Chinese society and introduced many elements, for example introduced civil service exam on the merit base rather than birth, under the imperial examination system. After Lengthy rule of three hundred years, the Han Dynasty saw period of disunity in areas of Mongols and north tribes. This was the time, when Buddhism was introduced.

In 581, Sui Dynasty came into power and connected north and south regions of China through constructing Grand Canal. From 618 until 907, the Tang Dynasty ruled. It was the era of poetry and art and territorial expansions towards west and north were achieved. Another era of art from 960 to 1279 was under the song dynasty, fallen by Mongol leadership of Kublai Khan, who established the Yuan Dynasty and Beijing was declared capital. In 1368, the Ming Dynasty took over, this was an era of trade 
expansion. Ming ruled for 300 years.

From 1644 until 1911 the Qing Dynasty, territory expanded into Tibet and Magnolia. They believed in strict isolationism, caused their down fall, as they were far behind the standard of Western technology. Foreign traders with opium bags came into China by sea. In 1800, the Qing banned opium but west refused to accept the decree and retaliated. Resultantly, four opium wars were fought. Western powers defeated China and established many sea ports, divided the nation into spheres of influence, China had to lose Hong Kong to the British and nearby territories on lease for hundred years.

The Qing and foreigners were overthrown by a group of rebels, the Righteous and Harmonious Fists or the Boxers. Qing tried to compromise with boxers but in 1912 Sun Yat Sen broke and he became the president of Chinese Republic. A student protest against Western influence on $4^{\text {th }}$ May 1919 got strength. It is also called May Fourth Movement. Such a weakened state of country gave rise two political parties. Mao Zedong in Beijing University with other students laid the foundation of communist party, other was nationalist party, led by Chiang Kai-shek. They tried to join forces but due to disagreement lead to a civil war. In 1931, the Sino Japanese War began. Japan directly attacked on Chinese arts Capital Nanjing in 1937.It resulted in 30,000 deaths and large scale destruction, Japan withdrew its forces after World War II.

The communists were forced to seclusion to the North by the Kuomintang having military superiority. It is year called the Long March Communist agenda is social equality. During the Long March, Communist redistributed the land among the peasants from the rich landlords, many of them joined communist, and increased its strength. On the other side, Nationalist had control over cities, in 1940's, the nationalist were surrounded due to the growing number and strength of communist in the country sides. Chiang's army was left alone. Chiang fled to Taiwan with his two million followers. Nanjing capital at that time came under communist's regime. On $1^{\text {st }}$ October 1949, Mao Zedong, the chairman of the Chinese communist party, established People's Republic of China. He died in 1976. (Countries and their Cultures, 2017). 


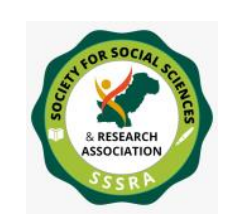

Social and Cultural Relations between ..

\section{Confucianism Philosophy of Life}

The main ancient philosophy of China that most importantly influences on Chinese people everyday life is Confucianism. Its founder was Master Kongzi (Confucius, 551-479 B.C.E) writing at around the time of Socrates, but before Jesus Christ. "Three bonds of loyalty bound the society (loyalty to the ruler, filial obedience and fidelity of wife to husband). Two of these were set within the family and all represented relationships between superior and subordinate" To attain Ren, practice of Li is must (Childe \& Warner, 2003, p.7).

There are three basic guides in Confucius belief system ruler guides subject, father guides son, and husband guides wife and five constant virtues are "benevolence, righteousness, propriety, wisdom and fidelity", and the doctrine of the mean is 'harmony'. Some of the basic ethical concepts and practices include Ren, Yi, and $\mathrm{Li}$ and Zhi. The main principle of Confucianism has been laid down is Ren ("humaneness" or "benevolence") is the supreme virtue, that follower should attain. Confucianism is based on the system of social and ethical philosophy rather than religion. It is called a Civil Religion. Li in itself gave one a moral status or prestige. This moral prestige in term gives one influence over people.

Confucius said, in order to establish one self, one has to establish others. This is the way of a person of Ren". The basic ethical concept to keep upholds righteousness and moral good is $Y i$. Another basic moral code is the ability to understand, what is right and fair or the opposite. In the behavioral attitude by others is Zhi If there is failure to follow the moral values of Ren and Yi, Confucianism holds one in contempt (Childe \& Warner, 2003, p.8).

Confucianism is an ethical and philosophical system. These Confucius thoughts and teaching are being followed so religiously by people that became a belief to educate people. It is not a real religion. (Berling, 2020). The Confucius slogan for his civilization was 'Benevolence, Justice, Courtesy, Wisdom and Trust'. Chairman Mao Zedong coined a two-word slogan as the core values of the Communist 'serve the people'. Harmony and benevolence express the idea of "Peaceful Coexistence was proposed by Premier Zhou Enlai that 
'Community of common destiny' as proposed by president Xi Jinping (Xiguang, 2016).

\section{China: Societal Values and Culture}

The core Han culture: Han culture is very important to understand in the context of how China developed. Han dynasty ruled nearly 400 years, unified modern China, called as golden age, established many customs, traditions and traditional Chinese beliefs, Han dynasty emperor was Liu Bang, history remembers him as emperor Gaozu. The credit goes to the Han that the "ancient writings of the Chinese philosopher Confucius were made the state doctrine of China and formally codified into Confucianism". Due to powerful empire, Han people and culture spread in China, other ethnic heritages did join the Han dynasty (Muscato, 2016).

\section{Religion and Beliefs}

The China Family Panel Study (EFPS) 2014 survey published in 2017 states that, China has a religious pluralism, that includes Buddhism, Taoism, Islam, Christianity, Judaism and other religions in minority "Chinese folk religion /unaffiliated (73.5\%) Buddhism (15.87\%)other religious organizations, including folks seat and the Taoist church (7.6\%),Christianity (2.53\%),Islam(0.45\%)"(Wikipedia.org, 2016).

\section{Religion of China: And Beliefs}

China is a socialist state, officially atheist (Godless). "The philosophical system evolved by Lao -tzu and Chuang Tzu advocated a life of complete simplicity and naturalness and of noninterference with the course of natural events, in order to attain a happy existence in harmony with Tao" (Mark, 2016, February 22). Taoism rejects rank and class which is not so in Confucianism, it also shuns competition, ambition and aggression.

In China Buddhism was introduced nearly 2000 years ago people adopted gradually and developed into three sections Han, Tibetan, and southern Buddhism. It introduces different cultures specially literature, art and ideology. The main goal of Buddhism belief is Nirvana, a place or state characterized by freedom from pain, worry and the external world (Travel China Guide, 2020).

Almost 185 million people have faith in Buddhism. Confucianism. 
and Taoism. Elements of all three are practiced. They also worship various Gods and Goddesses related to responsibility of different aspects of life and profession.

In Buddhism, Central religious figures are called monks, who devote their lives for meditation and prayer whereas Confucianism and Taoism don't have such concepts. Dalai Lama is a Central figure in Tibetan Buddhism, translated as "Ocean of Wisdom". On the death philosophy Dalai Lama, belief is that he will be reincarnated and it is monk's duty to search out his spirit, in a new born baby.

\section{Chinese Languages}

Han Chinese language is widely spoken. Dialects are unintelligible. Manderin is the most important Chinese tongue. Which is also called Putonghua which means common language or ordinary language. Commonly, modern spoken language at all levels has Beijing dialect.

There are sixty thousand characters, difficult and hard to learn but only five thousand are used in everyday languages. Writing system is same as thousand years old. Chinese language does not represent sounds but concepts, as it is written in pictographs and ideograph.

\section{Chinese Art}

Chinese art is the reflection of Chinese class structure of different times in Chinese history. Chinese art has been produced by unique, skilled craftsmen, mainly for the feudal and royal courts, during the Shang and early Zhou periods, under the authority of the court. "Chinese art is greatly influenced by the countries rich in spiritual and mystical history. Many sculptures and paintings depict spiritual figures of Buddhism (Zimmermann, 2017, December 12). Chinese graphic arts paintings are highly appreciated.

Mostly paintings have been writing by artist or quotes of later era scholar. It can be a poem, commentary on the work or a dedication. Particularly communist politician carry this practice to enhance their painting with writing of Chairman Mao" (Countries and their Cultures, 2017). 
Chinese cultural project leader Echo Lee told the reporters, "that under the China Pakistan Cultural Corridor (CPEC) would bring the people of two countries closer. Under the CPEC, cultural shows as well as musical concerts, film festivals and fashion shows will also be organized in each other's countries. Media exchange programs will also be enhanced under which the media personnel from both the countries will be imparting training in latest media trends" (Wasif, 2018, February 06).

Nowadays, Media is the biggest transmitter of culture of any country. "The CPEC master Plan reveals the plan to broadcast Chinese contents on Pakistan televisions through Digital Television, Terrestrial, Multimedia, Broadcasting, and (DTMB). It was even reported that these services would be extended to the mountainous areas of Pakistan, where you still find people living the traditional life" (Niazi, 2017).

\section{Chinese Holy Places}

Buddhist temples contain pagodas as an internal part; also they display statues of the Buddha in gold, jade and in different stones. Their Worship is not communal. It is usually in the form of individual prayer or meditation. Taoist temples usually have yellow or green roof, decorated with images of Gods and Dragons. Physical exercise is the spiritual practice, also imitates animal movements, e.g. deep breathing with graceful gestures, for all ages, in parks or public places in groups. At the time of the new moon and the full moon, Buddhist and Taoist temples perform special prayer gatherings.

Chinese New Year or spring Festivals fall between mid-January and mid-February, It is organized as largest festival celebration of the year. People wash their houses, a symbol of new start in the life, children are gifted with money in red envelops; believe a sign of good luck. Between late March and late April they visit Taoist temples to celebrate Guanyin (the goddess of mercy) birthday. In May and June the birthday of Mazu (The goddess of Sea) is celebrated. In Mid-April the water splashing, bathing festival is observed to wash away bad luck in Yunnan province. Sacrificial ceremony and offerings of food to the cattle in the spring is called cattle -soul festival. In September or October Chinese celebrate moon festival or mid-autumn festival with paper lanterns, 
fireworks and moon gazing. On $28^{\text {th }}$ September the birthday of Confucius, Chinese hold pilgrimages to his birthplace in Shandong province.

\section{Chinese Culture: Death and Life after Death}

Traditionally funerals are large depending upon the diseased social and political status or standing. Possessions are also buried, 'to ensure entry into the next world. Chinese mourners dress and cover their head in white cloths.' In Buddhist practice, ancestral worship is very significant, every house contains a small alter dedicated to deceased family members. To visit the burial place, $5^{\text {th }}$ April is dedicated to ancestors for paying respect. This day is called Tomb Sweeping Day. Food is placed on their graves as an offering. It is believed that during late August to late September is the time when spirits of dead are returned to the earth called Ghost Month, It is believed that this period is not the right time to start new things in businesses. In case of any death during this period the dead is buried after the expiry of this period (Countries and their Cultures, 2017).

\section{Pakistan: Social and Ethical Values}

Pakistani culture originates from the period of Indus valley civilization 5000 years ago. It was considered to be the urban culture of Indian subcontinent. Since 1947 culture has been blending with the dominant Islamic cultural value and traditions. It identifies as culture of Pakistan. Many ethnic groups together make the society and culture of Pakistan. There is a long list of ethnic groups which include Punjabis, Potwaris, Kashmiris, Sindhis in east, Muhajirs, Makrani in the south, Balochistan, Hazaras and Pashtuns in the west, Wakhi. Baths, Shinaki and Burusho communities in the north. Culture of these communities is greatly influenced by the neighboring countries. These ethnic groups have different cultural aspects, in dressing, food and religion. Islamic customs still prevails.

Social and ethical values of Pakistani culture are very distinctive. Religious, factors is quite dominant as a whole, but it is quite diverse. Pakistan culture is the Combination of different races, these are Huns, Turks, Persian Arabs, Mongols and various Eurasian groups. These races 
are quite different in dress food, religion. Pakistan culture comprises of Punjabis, Sindh's and the tribal cultures of the most Pakistani provinces. Their cultures are being influenced by India, Central Asia and the Middle Eastern cultures, but their local languages are different. Tribal customs in rural areas of Pakistan are still the same, as dating back hundreds of years. In general, there has been a strong impact on traditional culture, due to the fact of globalization. Pakistan traditional dress is Shalwar Kameez gradually changing to shirt and trousers. This change is due to the fact that many Pakistanis are living in abroad. Other countries restaurants and franchise are doing great business in Pakistan. In this context, media has been contributing wider role. Many channels of different countries are being played in Pakistan that is an offshoot of foreign culture on Pakistani traditional culture. New generation tries to practice cultural change, but the positive aspect is, that they gain knowledge.

Indian and English movies are being watched for ages in this region. "Pakistan culture has never been purely Islamic from our mostly Hindu Inspired wedding ceremonies to our varying folk dances and dress"(Amir, 2016). Beside all these facts, Pakistani Muslims are very particular and religiously follow the Islamic practices. These cultural changes are, due to some extent, a large number of Pakistanis are living abroad in UK, USA, Canada, Australia, Middle East as well as in Scandinavian nations, and they more often visit Pakistan as a home land. The major factor modifying traditional culture is globalization.

\section{Pakistan Language}

Urdu is the official language of Pakistan. It is included in the syllabus up to the bachelor degree. It is widely spoken in Pakistan and India. Urdu is quite close to Hindi. It has been developed in the Indian Subcontinent. It is a member of the Indo-Aryan group within the Indo European family of languages, spoken in the region around Delhi. Urdu is a mixture of Arabic, Persian and Turkish. It is also called Hindustani in India. 


\section{Pakistan: Religion}

Pakistan is an Islamic state about $94.4 \%$ are Muslims (Sunni $85 \%$ $90 \%$, Shia $10 \%-15 \%$ ) remaining minorities include, Christianity, Hinduism, Parses and others 3\%. (2010 est.) (Central Intelligence Agency, 2010).

Islam in the $7^{\text {th }}$ century CE, was promulgated by the Prophet Mohammad in Arabia, It means surrender, and acceptance. Surrender to the will of Allah (God), sole creator, sustainer, restorer of the world. Submission to Allah means submission to holy-sacred scriptures. The Quran, The Holy book was revealed to His messenger Mohammad who was the last Prophet. The lineage of Prophet starts from Adam, Noah, Abraham, Moses, Solomon and Jesus, Quran was completed through revelations to Prophet Mohammad. The archangel Jabrael revealed. There are 114 suras in Quran. The Suras revealed at Macca mostly focus on ethical and spiritual teachings and the day of Judgment and Sura's revealed at Medina focus on social legislation, politico-moral principles for constituting and ordering the community. Sunnah, in Islam means the example of the Prophet i.e. His words and deeds as recorded in compilation known as Hadith (report). Hadith provide the written documentation of the Prophet's words and deeds (Mahdi, Rehman, \& Schimmel, 2016).

\section{Islamic Teachings}

Islamic fundamental beliefs are called Articles of Faith. They are Belief in one God, Belief in Revealed Books of God, and Belief in Angels Belief in prophets of God" Belief in Day of Judgment and Belief in Destiny and Devine Decree.

\section{Comparative Study of Chinese and Pakistani Islamic Culture}

China has very old and continuous civilization. It is a communist state, being ruled by the Chinese communist party. Officially atheist (godless) is a person who denies or disbelieves the existence of Supreme Being or beings). A theory advocating elimination of private property, a system in which goods are owned in common and are available to all as needed. 


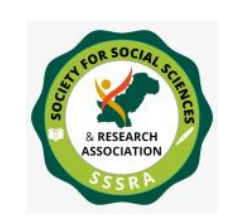

Social and Cultural Relations between ..

"Communist, is an individual who believes in the socioeconomic structure known as communism". Communists usually share similar ideologies as socialists and are interrelated fundamentals. Some of the most well-known communists leaders include Karl Marx, Vladimir Lenin and Mao Zedong (Chinese). Communism is a government system in which authoritarian, single party controls state-owned means of production. (Dictionary.com 2020). There is a great diversity between the religions of Pakistan and China. The religious doctrine (ideologies) are for the guidance of followers, social movements and institutions. There are possibilities of similarities between two religions on the humanitarian ground. Islam starts and ends with an eternal belief in oneness of Allah (God), His Messengers mentioned in Quran, in the finality (Qiyamah) of this world and the resurrection of the dead for Divine judgment; and His angels. Chinese are communist, atheist, Buddhist; they don't believe in oneness of Allah (God) neither His messengers, but believe in worshiping many gods and goddesses e.g. the goddess of mercy (Guanyin). The goddess of the sea (Mazu), Guanyin, Jade Emperor and Buddha are holy figures. In Islam, Prophet Mohammad (PBUH) and all other prophets of Allah, starting from Adam, Noah, Abraham, Moses, Suleiman and Jesus are Holy figures.

In Chinese religion, supreme god is Shang. During Xia dynasty and Shang dynasty their Prophets or soothsayers behaved as priests. Much of Chinese culture is based on the idea that a spiritual world exists. Islam does not accommodate such a worldly religion. Islam is based on Divine religion teachings. That there is only one incomparable God (Allah) and that Mohammad is the messenger of God. Islam states 'that God is merciful, all-powerful and unique', guides the mankind through His Prophet, and revealed scriptures and natural signs. Quran is the Holy Scripture of Islam. It contains verbatim word of God. Teachings of Prophet Mohammad are called Sunnah and hadith are composed of words and actions of Prophet Mohammad.

According to Islamic teaching, Muslim should perform Hajj , once in a life time, if they can afford. Chinese make pilgrimage at the birth place of Confucius on his birthday (28 September) in Shandong province. He was the Chinese philosopher (551-479 BCE), considered as God of Culture. The core of the Confucianism is humanistic. Confucianism means 
refined school, developed from hundred schools of thought from the teaching of Confucius" (Wikipedia, 2016).

Chinese practice Confucianism and Taoism, as traditional religions. Elements of Confucianism, Taoism and Buddhism are quite close to each other, Chinese practice them all three.

Humanistic main teachings of Islam are laid down in the divine Holy book Quran, Sunnah and Hadith. Islam is a monotheistic religion. Islam is a divine religion whereas Buddhism, Taoism and Confucianism are manmade religions. They believe in "Reincarnation (rebirth) as the religious or philosophical concept that the soul or spirit, after biological death, begins a new life in a new body that may be human, animal or spiritual, depending on the moral quality of the previous Life's actions" (Chinabuddhismencyclopedia, 2016). "The concept of reincarnation of human soul is totally rejected in Islam, according to Islam dead goes to Barzakh and stay there until The Day of Judgment where it will be decided w whether he should go to paradise or hell and then that life will be eternal. Mosques are the places where Muslims go to offer their prayers five times a day and also at home, Chinese place of worship is called temple colored roofs adorned with images of gods and dragons. Pagodas are integral part of Buddhist temples. Buddha statues are displayed sometime various sculptures in gold, jade or stone are displayed. In Islamic mosques such things are prohibited.

Chinese dragon is the well-known aspect of Chinese culture. Dragon is the 'main symbol of the Chinese nation.' It is believed that it is made up seven animals and Chinese are descendants of dragon which is highly embedded in their culture. It is adopted as national icon and has been worshiped as a source of community wellbeing. Chinese dragon in reality doesn't exist, one out of twelve Chinese Zodiac signs, Chinese ancient emperors were given identification as the sons of dragons. It is said, the tribe leader "Yan Di was born, thanks to his mother's telepathic communications with a mighty powerful dragon."

These beliefs in ancient China originated through the rise of dynasties in $2500 \mathrm{BC}$. Chinese dragons also have different colors. "According to every popular legend in China, the Chinese dragon King 
has nine sons. They all look different and hold various powers". (ninechinese.com, 2016) "Chinese people refer to themselves as the descendants of Yandi and Huangdi (a legendary tribal leader) as well as the descendants of the Chinese dragons" (Chinahighlight, 2016).

"The Chinese dragon is a mythical creature, traditionally symbolize potent and auspicious powers. Particularly control over water, rainfall, typhoons and floods, also a symbol of power, strength and good luck for people who are worthy of it" (Wikipedia, 2016).

Western dragon is considered as malevolence ill will, hatred.

The teaching of Prophet Mohammad (PBUH) is totally against such concepts; nothing can happen without the will of Allah (God). Such mythical and folklore are only to mislead mankind. Ancient Arab history shows the popularization of dragon myth by Judaism and Christianity in Arabia. But after the final guidance from Allah (God) through chosen Prophet Mohammad (PBUH) for all mankind, lead to the righteous faith of Enlighten Islam.

Every Muslim must have full faith in oneness of Allah (God), five pillars of Islam and Islamic teachings and must not allow homage for such contradictory mythical concepts in their Islamic society of Pakistan and in the Islamic world. Such satanic beliefs are pagan religion. Nothing ever surprises a true Muslim, who leans on Allah (SWT) knows best.

In response to my question, what will be the consequences of Chinese cultural onslaught on Islamic society of Pakistan? Dr. Syriac Nellikunnel opines, "I don't think it is an onslaught on Pakistan's culture. China is communist state whereas Pakistan is an Islamic state. There is a vast difference in Chinese and Pakistani culture and language. i.e. we will look at Malaysia, have many Chinese projects managed by Chinese from mainland China. There are not many cases of inter-racial Malaysian and Chinese getting married or Chinese getting settled in Malaysia" (Nellikunnel, 2018).

There has been long, at all level friendship between China and Pakistan because there has not been any territorial dispute between two countries, like Pakistan has with India, China always stood with Pakistan 
in any difficult time. But there are great cultural disparities between both countries. There is a basic and vast difference in the Urdu and Chinese languages. The official language of China is Mandarin, It has Beijing dialect. It is quite difficult to learn as written in pictographs and ideographs symbols. Urdu is the official national language of Pakistan. It Originated dates back to the Islamic Mughal Empire in India, dialects include Dakhni, Rekhta and dialects of Delhi region, including some vocabulary from Arabic, Persion, Turkish and Hindi (Parekh, 2011) In terms of lexicon, Urdu has borrowed extensity from source of Arabic and Persian. (Zeidan, 2017).

Introduction of Chinese language in Pakistan through the development of CPEC will be a great damage to national language of Pakistan, Urdu; Ninety nine percent of population in Pakistan is not even familiar with Chinese language. Islamic teachings have very strong roots in Pakistani culture. Now many private institutes, colleges and universities are imparting Chinese language teaching courses, so that Pakistani can communicate with Chinese companies at the level of business transactions. Naturally during all these processes, cultural exchange will be definitely, harmful to traditional Islamic cultured society. It should be handled by Pakistan government to keep it to the limited level.

Flag description, red color in Chinese flag represents revolution whereas yellow stars symbolize, four social classes united under the communist party China. The flag description of Pakistan, a large white crescent and star in the center of green field represent the traditional symbols of Islam and white band on the side represents the role of minorities and their religion.

The Cheongsam is regarded as the national dress of China, one piece garment as address for women and similar long shirt for male dress. In 1912 many Chinese adopted Mao suit style called Chinese tunic suit. Now the Chinese are more into western fashion in their culture. Pakistani national dress is Shalwar Kameez for men and women and similar in all the four provinces of Pakistan including Azad Kashmir. They are now adopting into western style dress genes and shirts. Dupatta is an essential part of the Shalwar and Kameez for women, to cover their head, neck and chest. Abaya to cover head and to cover overall body is also being used, 
popular in women when they go out in the markets. Islam prohibits nudity and declared it punishable sin. In Balochistan and KPK provinces women strictly abide by the Islamic values. Baluchistan and KPK hold extremely conservative Islamic traditional culture and almost in the whole Pakistan. They would not allow any kind of nudity in their cultural domain, in the context of CPEC project.

Chinese painting art is very well known in the world. It has very old rich history, starting from Han Dynasty (202 BC) on ward. Chinese painting is more like calligraphy; traditionally it is done on rice paper or thin silk using brushes, ink and dye. Chinese painting highlights vast area of subjects, landscape, flowers, birds, portrait, animal and insects. "Chinese art is greatly influenced by the country's rich spiritual and mystical history. Many sculptures and paintings depict spiritual figures of Buddhism" Zimmermann, K. A. (2017, December 12)

The outstanding and prominent creative art, painters of Pakistan are Ismail, Gulgee and Sadequain and many others in abstract art. The most popular folk art of Pakistan is vehicle art. The Pakistan National Council of the Arts (PNCA) has established National Art Gallery, the Sadequain Gallery and National Music and Dance center. Mostly Chinese painting carries the writing of Mao and Quotes, poems, a dedication or commentary on the work by artists or by scholars. Whereas Pakistani paintings are famous for mural and calligraphy, miniature paintings, contemporary paintings, paintings on socio political themes, panoramic paintings and fantasy art. Paintings on culture and anti-nuclear weapons, poetic with Afghan refugees suffering in the paintings. Artists in Pakistan have shown great contribution in portraying Pakistani culture, human suffering and destruction of human lives, role of Chinese painting sculptures in Pakistan under CPEC would increase Chinese spiritual and communist thinking among Muslim population of Pakistan

In Chinese cuisine beside other things, which are included in Pakistani cuisine, is too much intake of pork. Islam has declared Pork haram, means forbidden. It is stated in the divine book Quran and Islamic Law. In Quran it is mentioned in the following verses (i) 2:173 (ii) 5:3, 6 (iii) $6: 145$ and $16: 115$. Due to the Chinese influx in Pakistan, through 
CPEC project by 2030, there will be much pig farms productions. Transportation of pork and its consumption is against the Islamic teaching.

Balochistani culture is basically tribal, male dominated and extremely conservative, ruled by tribal chieftains Mirs, Sardars and Nawabs. Common Islamic religion is the binding force among various ethnic groups. For them, guests are blessing of God but culturally infidelity and betrayal is never forgotten. Many families live on barren mountain have no social life specially women, who are treated badly, as patriarchal tribal culture. Women literary rate is $14 \%$ whereas $50 \%$ school going age children have no excess to school. Economically Balochistan is far behind being geographically largest province of Pakistan and covers $44 \%$ of the total land area of Pakistan, with very low population 5\% (8 million) of the whole population. Gawadar is one of the districts, situated to the south western at Arabian Sea coast of Pakistan. It was a just a fishing village port city but since 2013, under CPEC project; Gawadar port development is on full scale. Officially it was handed over to China under the contract with China at the cost of $\$ 248$ million. Pakistan has given over 2000 acres of land on lease in the Balochistan province, to China for 43 years.

In response to my question, what will be the consequences of Chinese cultural onslaught on Islamic society of Pakistan? Col (R) F. Maqbool Afridi opines, "We should educate our people about our religion and cultural values to compete the onslaught of Chinese culture. Influx should not be at large scale, limitations should be defined at the government level, our Islamic and cultural values should not be hurt" (Ahmed, 2017, March 13)

China is the largest saturated populous country in the world. Balochistan has enough vacant barren land to accommodate Chinese influx due to CPEC development. By 2030, there is a strong view that Chinese population in Balochistan will be in majority, leaving the locals in minority. It will create the room for Chinese cultural influx. Chinese atheist, communist followers of Buddhism would practice religious practices, for that temples will be built.

Mixed Chinese and Pakistani gathering will be common. Nudity of 
Chinese people and in their films will be watched even in the caves settlement on the mountains of Balochistan. Percentage of Chinese and Pakistani marriages will be higher to produce mix generation. Chinese people would organize their important religious, spiritual, events and worships. Chinese national days will be celebrated with true enthusiasm in Pakistan. Cultural onslaught of Chinese society will bring clash with the traditional Islamic society of Pakistan. Pakistan is an Islamic Republic, majority 94\%of the people are Muslims, have strong faith in oneness of Allah (God), five pillars of Islam and Islamic teachings of Quran and Hadith. Pakistani Islamic traditional society must not lose its identity.

\section{CONCLUSION}

Silk Road Economic Belt (SREB) and Maritime Silk Road (MSR) together form the Great vision of President Jinping's OBOR initiative. A vision to bring Social, Cultural, Economic and Political greater integration with participation of China will come true. All Asian countries, Russia, Europe and South Pacific will be connected by land corridors. Indian Ocean, Arabian Sea, Persian Gulf and Mediterranean will share a greater destiny. Along the OBOR there have been great civilization zones, of Turkic, Persian, Arab, Russian, Indian and Chinese culture. These cultures co-existed with the different ideologies, peacefully at the same time for centuries. Cultural diversity still exists and national ideologies can never be challenged. But through the New Silk Road civilization along OBOR routes, will encouraged diverse cultures in the spirit of peaceful coexistence. People to people contact, tolerance, a winwin cooperation and trade friendly policies will emerge on the horizon. This will reshape China's geopolitical, geo economic and geo-civilization ambit of influence. Through commercial channel it will provide the platform of human social interaction. OBOR will be a channel of multiracial, ethnic, cultural, values, traditions and religious coalition. Therefore, OBOR is an economic zone but it is more cultural and social zone. OBOR does not promote one particular ideology and religion but supports multi polar policies, culture, history traditions and tribes. One of Chinese slogans, is creating a shared future / destiny for mankind and OBOR is a mega multidimensional step in this direction. 
Baluchistan is very less populated and backward area with high poverty rate, low level of health care and education, lack of employment opportunities, high migration to other provinces. It holds strong Islamic values \& traditions. Chinese influx in such areas and otherwise would bring unethical values, through Chinese films, dramas, documentary films. Chinese language classes will damage local languages through their Buddhist and Confucius beliefs and teachings. China is a biggest consumer of Pork and pork made products. Will Pakistani society allow the production of pork in the country on commercial scale? This will aggravate people's mind, and may cause hostility and clash in the long term.

\section{RECOMMENDATIONS:}

1) Successful execution of OBOR is not only the responsibility of China that has launched the initiative. Support and cooperation of all the countries along OBOR route is equally important for its timely completion. In this context, countries must condemn and defuse confrontation, mutual conflicts and settle political instability and social unrest within their domain and at international level.

2) Role of Silk Road history and culture should be promoted on international affairs forums. Chinese government is significantly playing its role through organizing festivals, exposing its heritage awareness through museums and archaeological cultural surveys. "Thirty-four of which are recognized by UNESCO as Outstanding Universal Value and Worthy of its prestigious world Heritage List" (Winter, 2016).

\section{REFERENCES}

Ahmed, N. (2017, March 13). Gwadar, Chabahar and Dubai: Less than 100 kilometers apart, Gwadar and Chabahar are emerging ambitious 
rivals. The Express Tribune.

https://tribune.com.pk/story/1354422/gwadar-chabahar-dubai

Amir, M. (2016). What is Pakistani culture anyway? Dawn www.dawn.com/news/1287968

Berling, J.A. (2020) Confucianism. Centre for Global Education. https://asiasociety.org/education/confucianism\#: :text=Confucianism $\% 20$ is $\% 20$ often $\% 20$ characterized $\% 20$ as, ideals $\% 20$ of $\% 20$ traditional $\%$ 20Chinese $\% 20$ society.

Brown, L. (2018). Then Belt and Road Initiative. Lehman Brown International Accountants. https://www.lehmanbrown.com/insights$\underline{\text { newsletter/belt-road-initiative }}$

Cai,P. (2017).Understanding China's Belt and Road Initiative. Sydney, Australia: Lowy Institute for International Policy. Lowy Institute https://www.lowyinstitute.org/publications/understanding-belt-androad-initiative

Central Intelligence Agency. (2010) The world Fact Book. https://www.cia.gov/library/publications/resources/the-worldfactbook/geos/pk.html

Childe, J., \& Warner, M. (2003). Culture and Management in China. Cambridge, UK: The Judge Institute of Management, University of Cambridge.

https://www.jbs.cam.ac.uk/fileadmin/user_upload/research/workingpa pers/wp0303.pdf.

Chinese Buddhism Encyclopedia. com. (2016). Reincarnation http://www.chinabuddhismencyclopedia.com/en/index.php?title=Rein carnation

Countries and their Cultures. (2017). Culture of China. Retrieved from www.everyculture.com: https://www.everyculture.com/Bo$\mathrm{Co} /$ China.html 
Dictionary.com. (2020). Definition of Communist.

https://www.dictionary.com/browse/communist

Horton, P. B., \& Hunt, C. L. (1984). Sociology (6th Edition). US: McGraw Hill.

Hussain, R. (2017). Will CPEC negatively affect the social culture of Pakistan? Global Village Space.

https://www.globalvillagespace.com/will-cpec-negatively-affect-thesocial-culture-of-pakistan/

Mahdi, M. S., Rehman, F., \& Schimmel, A. (2016). Islam. Encyclopedia Britannica https://www.britannica.com/topic/islam

Mark, E. (2016, February 22) Taoism. Ancient History Encyclopedia https://www.ancient.eu/Taoism/\#: :text=Taoism\%20(also\%20known \%20as\%20Daoism,a\%20philosophy\%20and\%20a\%20religion.

Muscato, C. (2016). Han Chinese: Definition, Culture and People. http://study.com/academy/lesson/hand-chinese-definitio-culturepeople-html

Niazi, Z. (2017, June 12). CPEC: Socio-cultural impact. The Nation. https://nation.com.pk/12-Jun-2017/cpec-socio-cultural-impact

Parekh, R. (2011, December 17). Urdu's origin: Its not a camp language. Dawn https://www.dawn.com/news/681263/urdus-origin-its-not-acamp-language.

Taylor, E. B. (1871). Primitive Culture (Vol.1\&2). London: John Murray.

Travel China Guide. (2020). Religions \& Beliefs in China. https://www.travelchinaguide.com/intro/religion/

Tufail, Z. F. (2017).Implication of China Pakistan Economic Corridor. CPEC-A Game changer for the region. Institute of Cost and management accountants of Pakistan.26(2,March-April), 10. 
Wasif, S. (2018, February 06) Pakistan, China sign executive programme of cultural agreement: Chinese Minister for Culture Luo Sugang welcomed the minister and her delegation. The Express Triubne. https://tribune.com.pk/story/1627670/pakistan-china-sign-executiveprogramme-cultural-agreement.

Wikipedia.org.(2016).Religion in China. Retrieved from Wikipedia.org: https://en.m.wikipedia.org/wiki/religion-in-china

Winter, T. (2016). One belt, One Road, One heritage: Cultural diplomacy and the Silk Road. The Diplomat, 29, 1-5.

Xiguang, L. (2016). Building a New Civilization along the One Belt One Road Initiative. China-Pakistan Economic Corridor: A Game Changer.

Zeidan, A. (2017). Urdu language. Encyclopedia Britannica. https://www.britannica.com/topic/urdu-language

Zimmermann, K. A. (2017, December 12). Chinese Culture: Customs \& Traditions of China. Live Science. https://www.livescience.com/28823-chinese-culture.html 